\title{
Literary Translation through the Lens of Poststructuralism
}

\author{
Roghayeh Farsi \\ Iran Language Institute, Iran \\ Ebrahim Davoudi Sharifabad (Corresponding Author) \\ School of Languages, Literacies, and Translation, 11800 Universiti Sains Malaysia, Penang, Malaysia \\ Ghada Saeed Salman Al-Douri \\ Malay Language, Translation and Interpreting Section, School of Humanities, 11800 Universiti Sains Malaysia, Penang, \\ Malaysia
}

\begin{abstract}
The dichotomy between the writer and the translator is de-stabilized with the announcement of death of the author. This paper applies Gadamer's and Barthes's theories to literary translation in an attempt to reappraise the role of the translator. It is believed that the translator is involved in a triad act of transcodification. As the reader of the source text, he is an interlingual transcodifier, and as the writer of the target text, he acts intercontextually and intraliguistically. The given triad task pinpoints the limitations of some of Barthes's notions, specifically the inefficiency of his distinction between 'readerly' and 'writerly' texts. Viewed as such, the freedom of the reader/translator in the playfield of signifiance is challenged by the translator's interlingual and intercontextual transcodification. In a Barthesian key note, the act of translation is performance-based. Hence, the translator is involved in a doing-translation process. Utilizing Barthes's view on the processual nature of reading/writing, the present paper suggests a constant reassessment of the alreadytranslated texts which is necessary for keeping pace with globalization.
\end{abstract}

Index Terms - Roland Barthes, literary text, readerly, writerly, translation

\section{INTRODUCTION}

Conventionally, translation is viewed as a lowly paradigm and the translated text undergoes a subsidiary position visà-vis the hegemonic status of the original text. The translated text is therefore considered as the ultimate output of projecting the text from the source language to the target language. But when the translator translates literary works, such typical notions are challenged. Here, the translator attempts to capture the source text with all its stylistic and semantic merits and strives to produce it in the target language. The literary text's dynamics and multidimensionality involve a fuller and more profound appreciation of the source text including all of its inter- and con-textual features.

This paper adopts an interdisciplinary approach and touches upon literary translation and its challenges in the light of Roland Barthes's poststructuralist notions. Using Barthes's views on text and textuality, the present paper reveals the limitations of the semiotician's theories when applied to literary works. Simultaneously, Barthes's key theories are utilized in an attempt to reach a new definition of translation as well as its urgency in the postmodern world. Accordingly, the paper argues that translation is more than a mere projection, but rather a textual process; an interlingual performance, which is in constant change even after the translated text is concretized.

\section{THE THEORETICAL FrAMEWORK}

In the speedily-globalized world today, there is an urge to satisfy the basic human needs for communication across diverse cultural borders. Actually, the need to know each other and thereby to define oneself in the light of the other(s), and to determine one's position with respect to the other(s), has made translation an indispensable part of everyone's life. With regard to such great urgency, Albercht Neubert and Gregory M. Shreve have become aware of the political implications of the act of translation. Therefore, they argue that "Translation arises from a deep-seated need to understand and come to terms with others" (1999, p. 3). Acknowledging the danger of falling in the trap of political and ideological agendas, Neubert and Shreve explain further:

The capacity of translation for violence ... is no greater than its capacity to heal, to enrich and to educate. ... If we do not translate, then one of the most significant resources we have for conquering the isolation imposed by linguistic and cultural difference is squandered (1992, p. 3).

In literary texts, the danger of ideologizing one's translation is reduced. The issue of ideology and literary works is the core of Macherey's argument. Like any other works, literary works for him are pervaded by ideology. He proposes that in order to transcend the text's ideological forces, one has to begin with "the cracks in its façade, with those sites 
where the text is not fully in control of itself" (Bretens, 2001, p. 91). By focusing on what the text does not say and on what it represses rather than expresses, Macherey states that "literature reveals the gaps in ideology" (Bretens, 2001, p. 91). Similarly, Terry Eagleton is interested "not in what makes a text coherent, but in what makes it incoherent" (cited in Bretens, 2001, p. 92).

What really distinguishes Macherey's perspective from that of a poststructuralist like Roland Barthes is the former's belief in an objective truth. According to psychoanalysts like Jacques Lacan, philosophers like Derrida, historical theorists like Michel Foucault, and semioticians like Barthes, objectivity has been replaced by subjectivity and the longheld notion of truth has been rendered relative, context-bound and subjected to deferral and differential relations. For Macherey, the literary text is therefore the site of power struggle between the dominant ideology and counter-ideologies. However, the literary text for Barthes is the site of infinite play between the signifiers.

In his inaugural lecture at the college de France entitled 'Lecture', Barthes believes that language is "a medium of power" (1980, p. 19). He declares:

In language ... subjugation and power are confounded inevitably. If one regards freedom not only as the might to wrest from power but also, above all, the capability of not subjugating anybody, then freedom is possible outside language only. (1980, p. 20)

Barthes looks for the coveted freedom in literature arguing that "this salutary outwitting, this side-stepping, this magnificent lure which enables one to hear the language outside of power, in the splendor of a permanent revolution of language, is what I on my part call: literature" (1980, pp. 23-4). Thus, for Barthes, literature and literary texts are potentially beyond power.

In the light of this potentiality, Barthes distinguishes between the text and the work. In his essay, "From Work to Text," Barthes clearly pinpoints the differences between both of them. The following is the first difference:

The work can be seen (in bookshops, in catalogues, in exam syllabuses), the text is a process of demonstration, speaks according to certain rules (or against certain rules); the work can be held in the hand, the text is held in language, only exists in the movement of a discourse. ... The Text is experienced only in an activity of production. (1977, p. 286)

The other difference is that the work closes on a signified, but the text practices the infinite deferment of the signified. Barthes attributes the infinity of the signifier to the idea of playing. He mentions that "the generation of the perpetual signifier ... in the field of the text is realized ... according to a serial movement of disconnections, overlappings, variations" (1977, pp. 287-288). The plurality of the text is another feature which Barthes defines as the text's irreducibility. According to him, "the text is not a coexistence of meanings but a passage, an overcrossing; thus it answers not to an interpretation ... but to an explosion, a dissemination" (1977, p. 288). In fact, all these features lead us to view the text as a productive process rather than as a concrete entity. Indeed, it is this notion of text and textuality which, when applied to translation studies, sheds a new light on translation and translators.

For Barthes, literature is not a finished product, but "a writing practice" (Vollbrecht, 1994, p. 72). This view has been deeply rooted in his belief in the productivity of the text. He writes:

The text is productivity .... Even when written (fixed), it does not stop working, maintaining a process of production. The text works what? Language. It deconstructs the language of communication, representation or expression ... and reconstructs another language, voluminous, having neither bottom nor surface, for its space is not of the figure, the painting, the frame, but the stereographic space of combative play, which is infinite once one has gone outside the limits of current communication (1981, pp. 36-37).

A literary text for Barthes is considered as "the very materiality of the signifiers" (Klinkowitz, 1988, p. 48). This materiality is the realm of interaction, or what Barthes calls, play. It is the signifying practice where the text and the reader meet. For this meeting to take place, the text must be conceived as a production. Barthes replaces signification with signifiance. In this regard, Klinkowitz explains, "signification is something which happens on the level of product, but the signifying work of signifiance happens in the realm of production. The language of writing enters the reader in order to work him or her and undo previous senses of signification-signifiance is therefore the text actively at work within the reader" (1988, p. 78). Through this notion of signifiance, Barthes equates reading with writing:

Now, I am convinced that a theory of reading (that reading which has always been the poor relation of literary creation) is absolutely dependent on a theory of writing: to read a text is to discover - on a corporeal, not a conscious level - how it was written, to invest oneself in production, not the product. This movement of coincidence can be initiated either in the usual fashion, by pleasurably reliving the poetics of the work, or in a more modern way, by removing from oneself all forms of censorship to allow the text the freedom of all its semantic and symbolic excesses; at this point, to read is truly to write: I write - or rewrite - the text I am reading, even better and more searchingly than its author did (1985, p. 189).

\section{Statement of The Problem}

How can Barthes's revolutionary theories on reading be linked to translation studies? This question is addressed in this paper. The interdisciplinary methodology of the paper takes us back to Hans-Georg Gadamer and his notion of reading. For this hermeneutist, "Reading is already translation, and translation is translation for a second time" (cited in Chew, 1999, p. 1). It should be noted that the reading that Gadamer speaks about is not reading in its conventional form. Or rather, it is the Barthesian deconstructive theory of reading. Although Roland Barthes delegitimizes hermeneutics as 
a structuralist paradigm, his convictions on reading resemble those of Gadamer. This resemblance can be detected in the identification that Gadamer draws a distinction between reading and translation. On the similarities and differences between hermeneutics and Barthes, Peter Vollbrecht explains:

Barthes's view of the text productivity could also be subscribed to by a hermeneutic position which identifies the process of understanding with the event of a meeting of producer, text and reader. The idea, however, that, secondly, the text works as a deconstruction of language is not committed to the idea of understanding any more. It rather opens up a new horizon: the representative function of language is dismissed as metaphysical presupposition. (Maurya, 1994, p. 73)

Despite such a discrepancy, this paper hybridizes Gadamer's with Barthes's view and equates translation with writing. Translation is reading in a Barthesian sense. The translator meets the text and plays with its signifiers and lets the text work on him/her. This mutual relationship would in turn result in the translated text which is the outcome of the translator's attempt to rewrite the source text in the target language. For Barthes, signifiance is indeed a locus of activity.

Signifiance seeks texts not in their meaning but in their differences; it tries to say no longer from where the text comes (historical criticism) nor even how it is made (structural analysis), but how it is unmade, how it explodes, disseminates - by what coded paths it goes off (1977, pp. 126-127).

Such meanings are created when the reader is involved in the act of reading/writing. But what happens when the reader takes a step further in an endeavor to translate the text in the target language? In this stage, the reader is engaged in an interlingual signifiance. What happens in his infinite play with codes and signifiers of the text is extended to intralingual territories where linguistic borders of the source language meet those of the target language. The semantic dissemination which occurs for the reader/writer in Barthesian signifiance takes on a more complicated twist when the translator strives to recreate the same signifiance in another linguistic sign system with all its potential challenges and gaps.

Here, the translator's task contradicts his/her freedom in the signifiance. As the reader/writer of the text, s/he surrenders to the interplay with the signifiers of the text. But as the translator, s/he has to decide, choose, delete, add, and change the signifiers and codes of the source language in order to recreate them in another linguistic format. This ambivalence between translator as reader/writer and translator as translator of the text shows the limitations of Barthes's theories when applied to translation studies. The roots of these limitations could be traced back in the utopian vision that Barthes sets up in his theories on reading. If the Barthesian reader/writer comes to translate the text in the target language, s/he must not only be good at reading/writing, but also familiar with the linguistic capacities and limitations of both source and target languages. S/he should have the ability to create the requisite capabilities in the target language. Such an ideal concept can be easily theorized, but in practice it sounds unattainable. The idealistic view of the translator is similar to Barthes's utopia when the reader of the text becomes its writer. His idealism is depicted as follows:

In fact, the big problem is now to make the reader a writer. When the day comes that the reader is made into a virtual or potential writer, all problems of readability will disappear. If one reads an apparently unreadable text, in the movement of its writing, one comprehends it very well. Evidently a complete transformation - I should say almost an education - is needed; for that, one needs a social transformation. ... I would foresee ... such a thing as writing action, but supposing of course that there would also be numerous channels for the text, so that one would not be attacked by "boring" texts, if I can say - that is, inadequate. (Klinkowitz, 1988, p. 87)

Such a portrait of the ideal reader can also be true for the translator who has been "educated" to become a Barthesian reader before becoming a Barthesian translator. To be an ideal translator, one should be creative and innovative enough to reproduce a text in the target language with almost the same potentialities of the source text both in form and content so that the target readers can also experience the same signifiance. However, facts have proved the opposite. No matter how good the talents of the translator are, s/he has to decide on the most appropriate and closest form and content to the source text.

Thus, although the reader/writer might cherish the potentialities of the text while playing with its signifiers, he still has a number of options that have to be made in order to narrow down the text to specific codes. This reduction entails freezing the interlingual play on the signifiers of the text and imposing some codes over others. This experience leads to the conclusion that an ideal reader/writer never makes an ideal translator in the Barthesian sense. This is because the translator himself steps into the text as a transcendental signifier. Although s/he brings into the text other codes and sign systems, s/he has to enact, to decide, to privilege, and therefore to marginalize some options for the sake of others. This view of the translator makes the Barthesian distinction between readerly and writerly texts blurred and justifies his preference for the latter.

Barthes's objective in reading a text is to "reenact the writing of the text itself". Referring to this point, Klinkowitz mentions:

In this manner even rereading is more play than consumption, since everything is allowed to signify without limit until the accumulation of codes assumes its direction toward the text's total effect. 'Writerly value', as Barthes puts it, transforms the reader from consumer to producer, and in so doing activates the text itself. (1988, p. 80).

The writerly text is, as Barthes put it, "ourselves writing, before the infinite play of the world ... is traversed, intersected, stopped, plasticized by some singular system ... which reduces the plurality of entrances, the opening of networks, the infinity of languages" (1974, p. 5). By contrast, "to end, to fill, to join, to unify - one can say that this is 
the basic requirement of the readerly" (1974, p. 105). Accordingly, the text in which the reader is passive and has the least chance for play is readerly. The writerly text is the multilateral text which necessitates the reader's active participation in the process of reading. It is the writerly text which Barthes favors because it provides the fullest scope for the reader to rewrite the text. However, when the reader steps in the text as a translator, such a distinction proves inefficient. Being readerly or writerly, the translator is already the active reader, located in interligual moments, and the writer of the target text as well. It is true that with writerly texts the translator has to be more alert and active like any other readers. But this does not necessarily mean that in readerly texts the translator is passive because s/he is already involved, if not in the text's signifiance, at least in the interlingual significance when the two languages merge in order to give birth to another text. Therefore, this paper supports the view that Barthesian distinction between readerly and writerly texts is pale when applied to translation studies, because in each case the translator is always active and participant in the process of rewriting the text in the target language.

Marcel Proust reveals that in the process of writing, "the writer is producing complicated translation of the 'text' of the world: we generate a second translation in our attempt to return to the native tongue of reality" (cited in Chew, 1999, p. 1). Reality for Barthes fades away, but just like Proust, he believes in the textuality of the world. For Proust, the writer is a translator. By the same token, Barthes assigns to the reader the task of writing the text. Hybridizing the two notions, the paper suggests that both the writer and the reader are translators; each one is found to be involved in a continual play with signifiers. When this new approach is applied to translation studies, one can no longer see the translator as merely an interlingual communicator. Rather, s/he acquires a triad task: s/he reads, writes, and transcodes. In the Barthesian signifiance, the translator plays with the signs and lets the code work on him/her. Through this interplay, s/he rewrites the text. When s/he comes to the task of interlingual transcodification, the interplay between the signifiers extends to the realms of the two languages (the source and the target). The expansion of signifiance achieved would render the task of the translator ambivalently easy and difficult. It becomes easy and more joyful because the greater the significance is, the more options will be provided for the semiotic interplay. It becomes difficult due to a couple of obvious reasons. The first is that in the signifiance, the translator like any other reader is subject to the dangers of interpretation and misinterpretation. This would inextricably monitor his/her translation in a specific way which might result in the distortion and misinterpretation of the source text. The second reason is the intercultural and interlingual gaps which sharpen the differences between the two languages. It is the translator's responsibility, albeit restricted to the signifiers of the text, to decide how to close the gaps.

The other key issue in Barthes's theories is his focus on the erotic pleasure which arises out of the interplay between the reader and the text. In the "Theory of Text", he writes: "the text comes about, as soon as ... the scriptor and/or the reader begin to play with the signifier" (1981, p. 37). The text "comes about" implies that the birth of the text encountered between the reader and the text is an erotic event. In Peter Vollbrecht's words, "[t]he sexual-textual 'coming' happens along with the reader's erotic play with the signifying system and Barthes's idea of an erotic text takes shape" (1994, p.74). Barthes derives the notion of textual eroticism from his poststructuralist interpretation of 'meaning'. For poststructuralists, meaning is the function of the dynamic drive of the signifiers. Thus, meaning belongs entirely to the realm of the signifier and thereby to the reader. In the Barthesian signifiance, which is "the place of structuration" (1981, p. 38), it is a signifiance-in-the-making, that is, the coming of significance. This is why signifiance is thoroughly erotic. Barthes uses the French "jouissance" to describe the erotic pleasure of signifiance. This selection makes him differentiate between jouissance and pleasure. In Vollbrecht's words:

A text of jouissance cannot be interpreted because any attempt to talk about jouissance is tantamount to converting jouissance into pleasure, which is enjoyment restricted to cultural norms and identity. (1994, p. 77).

It is Barthes's jouissance, which he utilizes to designate that the unsayable pleasure experienced in signifiance can also be applied to the process of translation. It is out of the translator's/reader's involvement with the text that the translated text is born. As a result, the translated text "comes about" when the translator and the text interplay.

The Barthesian erotic involvement with the text has been long hinted at, albeit by variation, by the Earl of Roscommon (1633-85). Roscommon concludes his poem on the distinction between translation and writing as follows:

Then seek a Poet who your ways does bend,

And choose an Author as you choose a Friend;

United by this sympathetick Bond,

You grow familiar, intimate and fond.

Your thoughts, your Words, your Stiles, your Souls agree,

No longer his Interpreter, but He. (Wentworth, 1992, pp. 43-5)

On the concluding lines, Susan Bassnett elaborates:

The translator is to choose carefully, to seek an author with whom there is a sense of empathy. ... Through this relationship and by means of a close reading of the source author's work, a symbiosis takes place and the translator and author of the source text are fused in a mystical orgasmic relationship where they cease to exist as separate entities and become one (1996, p. 11).

In the mid-twentieth century when poststructuralist bells tolled the death of the author through Roland Barthes and Michel Foucault, it is the text which replaced the source author. Hence, it is with the text that the translator is fused in a demystified "orgasmic relationship" called "jouissance" by Barthes. Here, it is worth mentioning that the announcement 
of the death of the author has led to the death of the original, which in turn leads to a deconstruction of copy/original binary. In Bassnett's words, "once the original ceases to be, the translation can no longer be perceived as subsidiary to it and the translator is released from the thrall to the all-powerful source" (1996, p. 13).

Concentrating on Roscommon's last lines, Bassnett states that "the translator ceases to be an interpreter and becomes the source writer for the target reader" (1996, p. 11). She clearly re-echoes John Dryden's views on the role of the translator. Reclaiming his independence as a translator, Dryden reverses the master-servant dichotomy which rules over translator/ writer relationship:

A translator that would write with any force or spirit of an original must never dwell on the words of his author. He ought to possess himself entirely and perfectly comprehend the genius and sense of his author, the nature of the subject, and the terms of the art or subject treated of. And then he will express himself as justly and with as much life as if he wrote an original: whereas he who copies word for word loses all the spirit in the tedious transfusion (cited in Bassnett, 1996, p. 14).

In Dryden's perspective, the translator should "possess himself" of the original writer. This notion resembles Bassnett's announcement of the identification of the translator with the source writer. Both Dryden and Bassnett remind us of the Barthes's postructuralist reader/writer equation. Bassnett's interpretation and Dryden's viewpoint entirely support the claim of this paper that from a Barthesian perspective, the reader/translator identifies with the source writer. Thus, the translator's role no longer stands in a secondary position to that of the source writer.

Last but not least, the important theory of Barthes views the act of reading/writing as an act of performance. This idea is implicitly expressed in his own statement on the productivity of the text:

This [productivity of the text] does not mean that it is the product of labour (such as could be required by a technique of narration and the mastery of style), but the very theatre of a production where the producer and the reader of the text meet. (1977, p. 36)

Describing signifiance as "the very theatre of production" denotes that reading/writing is an act, a performance. It is not reading, but doing-reading. It is not writing, but doing-writing. Similarly, we can say that a translator does not simply translate, but is involved in a doing-translation activity. The performance-based dimension that Barthes gives to the act of reading/writing has its own connotations. It shows that he considers the reader/writer as an initiator embedded in the context. This point is clearly stated in his elaboration on jouissance:

Text of pleasure: the text that contents, fills, grants euphoria; the text that comes from culture and does not break with it, is linked to a comfortable practice of reading. Text of bliss [jouissance]: the text that imposes a state of loss, the text that discomforts (perhaps to the point of a certain boredom), unsettles the reader's historical, cultural, psychological assumptions, the consistency of his tastes, values memories, brings to a crisis in his relation with language. (1973, p. 14)

In the performance set up between the text and the reader, both work on one another, zero in on each other's fixed codes and deconstruct one another's sign system.

\section{THE IMPLICATIONS}

In the textual luminal space, both the text and the reader bring to the fore their contextualities which run encounter with each other in signifiance. Regarding translation as a performance would similarly do away with translation per se and relocates both the text and the translator in their culturally and linguistically different contexts. This new outlook on the identity of the translator and the act of translation foregrounds the very notion that translation is a process, an ongoing process in which not just the translator and the text are at work, but all the interlingual and intercontextual factors as well. This idea highlights the fact that translation-doing does not stop and does not end when the text is translated; rather it is already in a flux of change since the intercultural interstices are fluid. Therefore, the performance of translation is not a finished act since it is exposed to constant change as long as culture, identity and language are redefined and recharted. On the fluidity and instability of translation as an on-going process, Derrida refers to the dynamic entity of the act of translation, bringing texts together in a play of multiple meanings:

Difference is never pure, no more so is translation, and for the notion of translation we would have to substitute a notion of transformation: a regulated transformation of one language by another, of one text by another. We will never have, in fact never had, to do with some 'transport' of pure signifieds from one language to another, or within one and the same language, that the signifying instrument would leave virgin and untouched (cited in Bassnett, 1996, pp. 11-12).

The idea of performing translation accentuates the necessity of retranslating the translated texts. This revisit foregrounds the fluidity rather than the fixity of translation, opening up each time new horizons for the translated texts, on the performance of translation as well as the changes which occur to both target and source languages. The examination of such changes emphasizes the unavoidable interrelations of cultures and languages which lead to a better appreciation of the performance of translation and its urgency in today's changing world.

\section{REFERENCES}

[1] Barthes, Roland. (1968). Elements of Semiology. Trans. Annette Lavers and Colin Smith. New York: Hill and Wang.

[2] Barthes, Roland. (1968). Writing Degree Zero. Trans. Annette Lavers and Colin Smith. New York: Hill and Wang.

[3] Barthes, Roland. (1973). The Pleasure of the Text. Trans. Richard Miller. New York: Hill and Wang.

[4] Barthes, Roland. (1974). S/Z: An Essay. Trans. Richard Miller. New York: Hill and Wang. 
[5] Barthes, Roland. (1977). Image/Music/Text. Trans. Stephen Heath. New York: Hill and Wang.

[6] Barthes, Roland. (1977). From Work to Text. Trans. Stephen Heath. In Image/Music /Text. Stephen Heath. London: Fontana. 155-64. Also in Postmodern Literary Theory: An Anthology. Ed. Niall Lucy. Massachusetts: Blackwell. 2000): 285-292.

[7] Barthes, Roland. (1980). Lecture. Trans. Stephen Heath. New York and Wang.

[8] Barthes, Roland. (1981). A Theory of the Text. In Untying the Text. Ed. Robert Young. Boston and London: Routledge and Kegan Paul. 31-47.

[9] Barthes, Roland. (1985). The Grain of the Voice. Trans. Linda Coverlade. New York: Hill and Wang.

[10] Bassnett, Susan. The Meek or the Mighty: Reappraising the Role of the Translator. In Roman Alvarez and M. Carmen-Africa Vida. (1996). Translation, Power, Subversion. Clevedon: Multilingual Matters Ltd.

[11] Bassnett, Susan, and Andre Lefevere, eds. (1990). Translation, History and Culture. London: Pinter.

[12] Bretens, Hans. (2001). Literary Theory. London: Rouledge.

[13] Chew, Shirley, and Alistair Stead. Eds. (1999). Translating Life: Studies in Transpositional Aesthetics. Liverpool: Liverpool University Press.

[14] Cronin, Michael. (2006). Translation and Identity. London and New York: Routledge.

[15] Derrida, Jacques. (1981). Positions. Trans. Alan Bass. Chicago: University of Chicago.

[16] Dryden, John. (1962). The Life of Lucian, in George Watson (ed.). John Dryden: Dramatic Poesy and Other Essays, Vol. II. London: Dent.

[17] Hung, Eva. Ed. (2005). Translation and Cultural Change. Amsterdam and Philadelphia: John Benjamins Publishing Company.

[18] Klinkowitz, Jerome. (1988). Rosenberg, Barthes, Hassan: The Postmodern Habit of Thought. Athens and London: The University of Chicago Press.

[19] Neubert, Albrecht, and Gregory M. Shreve. (1992). Translation as Text. Kent: The Kent State University Press.

[20] Vollbrecht, Peter. (1994). Roland Barthes' Idea of the Erotic Text. In Postmodernism: A Discussion. Ed. Vibha Maurya. Delhi: Kalinga Publications: $70-80$.

[21] Wentworth, Dillon. (1992). Earl of Roscommon. Essay on Translated Verse. In Translation/ History/Culture: A Sourcebook. Ed. Andre Lefevere. London: Routledge: 43-45.

Roghayeh Farsi got her MA in English literature from Shiraz University and her PhD from University of Mysore in 2009. She has taught in different universities in Iran and right now is teaching literature in Neyshabur University. Her areas of interact are postcolonialism, translation studies, and discourse analysis.

Ebrahim Davoudi Sharifabad is a PhD candidate of Translation in the School of Languages, Literacies, and Translation, Universiti Sains Malaysia. He has been a researcher and instructor of translation studies for some years in Iran. His field of specialization in translation studies is translation theories, discourse analysis, literary translation, and mainly translation and linguistics.

Ghada Saeed Al-Douri is a Ph.D. candidate in Translation Studies, School of Humanities, USM. She has M.A. in Translation \& Interpretaion, University of Baghdad, 1993. She has worked as an instructor of Translation at Al-Balqa' Applied University in Jordan since 2003. She has also been an Arabic-English-Arabic freelance translator since 1989. 